\title{
Anti-inflammation and anti-platelet aggregation activities of the ethanolic extract of Graptophyllum pictum leaves in wistar rats
}

\author{
Yulia Ratnasari, Susanti Susanti, Binar Asrining Dhiani* \\ Faculty of Pharmacy, University Muhammadiyah of Purwokerto, \\ Jl. KH. Ahmad Dahlan, Purwokerto, Indonesia
}

Submitted: 07-02-2020

Reviewed: 17-03-2020

Accepted: 30-06-2020

\begin{abstract}
Graptophyllum pictum is a well-known folk medicine in Indonesia. The red leaves are widely used for their anti-inflammatory properties to relieve hemorrhoids. However, little is known about to what extent these properties can affect platelet aggregation. This study was aimed to determine the anti-inflammation and anti-platelet aggregation activities of the ethanolic extract of Graptophyllum pictum (EEGP). Apart from the ear and hind-paw edema assay, anti-platelet aggregation and bleeding time assay were also performed on male Wistar rats. The test animals were grouped into six groups: three treatment groups termed EEGP100, EEGP600, and EEGP3000 (received 100, 600, and 3000 $\mathrm{mg} / \mathrm{kg} \mathrm{BW}$ of EEGP, respectively), one control-solvent group (1\% CMC-Na), and two positive control groups (aspirin and Na-diclofenac). Based on the percentage of edema inhibition, absorbance change, and bleeding time, EEGP600 and EEGP3000 produced a comparable percentage of edema inhibition to that of Na-diclofenac, which was not found in EEGP100. Also, EEGP600 and EEGP3000, but not EEGP100, inhibited platelet aggregation as effective as aspirin (positive control). In conclusion, if administered at 600 and $3000 \mathrm{mg} / \mathrm{kg} \mathrm{BW}$, the ethanolic extract of Graptophyllum pictum can function as an anti-inflammatory agent that inhibits platelet aggregation.
\end{abstract}

Keywords: anti-inflammation, anti-platelet aggregation, Graptophyllum pictum

\section{*Corresponding author:}

Binar Asrining Dhiani

Faculty of Pharmacy, University Muhammadiyah Purwokerto

J1. KH. Ahmad Dahlan, Purwokerto, Indonesia

Email: binar_dhiani@ump.ac.id 


\section{INTRODUCTION}

Graptophyllum pictum (synonym: Justicia picta) is a popular folk medicine in many countries, including Indonesia. For three decades, the ethanol extraction of its red leaves has been known to exhibit anti-inflammatory activities (Shah, 2011), a precursor of hemorrhoid treatments. Prior scholars worldwide have been extensively reporting the myriad benefits of G. pictum (Goun et al., 2003; Olagbende-Dada et al., 2011; Srinivasan et al., 2011; Jiangseubchatveera et al., 2015; Jiangseubchatveera et al., 2017). Nevertheless, little to no research has revealed whether or not, and to what extent, the anti-inflammatory properties of G. pictum affect platelet aggregation.

Hemorrhoid is a condition where an anal sphincter, a group of muscles, is hypertrophic. It is also believed to occur because of the varicose dilatation of the anal veins (Loder, 1994; Patil et al., 2019). Aside from varicose dilatation, venous thrombosis is also a common trigger of internal hemorrhoids (Loder, 1994; Lohsiriwat, 2012; Patil et al., 2019). For this reason, the pharmacological treatment of these conditions mostly targets the reduction of vascular inflammation and thrombosis (Lohsiriwat, 2012; Sya'haya, 2016). Inflammation triggers the release of inflammatory mediators, such as histamine, serotonin, prostaglandin, and thromboxane A2, in the cyclooxygenase pathway (Capurso and Capurso, 2020). All of these mediators has arachidonic acid as the precursor. Thromboxane synthase converts arachidonic acid to prostaglandin $\mathrm{H} 2$ (PGH2), which then transforms into thromboxane A2 that later activates platelet aggregation (Capurso and Capurso, 2020). Therefore, the inhibition of inflammation will be followed by impeded platelet aggregation.

This research reported the anti-inflammatory activity of EEGP - which can trigger the inhibition of platelet aggregation - as an attempt to explore the development of EEGP for hemorrhoids treatment.

\section{MATERIALS AND METHOD}

\section{Materials}

The materials used in this research were red leaves of Graptophyllum pictum, carrageenan, arachidonic acid (Sigma), aspirin (Phapros), and Na-diclofenac (Phapros). G. pictum leaves were collected from Tegal, Jawa Tengah Province, Indonesia, and authenticated by Mr. Arif Husin, M.Si., the plant taxonomist at Botany Laboratory, Muhammadiyah University of Purwokerto.

\section{Animals}

The experiment used male Wistar rats aged 2-3 months old and weighing 150-250 g and allowed them to first acclimatize to the new surroundings for seven days. Before serial antiinflammation assay, these test animals were given EEGP at doses of 100,600 , and $3000 \mathrm{mg} / \mathrm{kg} \mathrm{BW}$ for seven days. They received a normal diet and oral administration of the test drugs and extracts.

\section{Methods}

\section{Preparation of ethanolic extract of Graptophyllum pictum (EEGP)}

G. pictum leaves were washed under running water, dried underneath a black cloth to prevent direct sunlight, and grounded into powder. Then, the powder was macerated using $96 \%$ ethanol in a 1:10 ratio for 24 hours and mixed every 6 hours for 24 hours. The macerate collected from the first process was processed with another cycle of maceration using half volume of the solvent. All the macerates from the first and second cycles were then mixed and evaporated using a vacuum evaporator to obtain a viscous extract.

\section{The grouping of test animals}

The test animals were clustered into four groups of treatment. Group I was a control-solvent group administered with $1 \% \mathrm{Na}-\mathrm{CMC}$ for seven days. Group II was a positive control group for the edema assay that was given Na-diclofenac at $12.6 \mathrm{mg} / \mathrm{kg}$ BW two hours prior to the assay. Group III was a positive control group for anti-platelet aggregation that received aspirin at $10.1 \mathrm{mg} / \mathrm{kg} \mathrm{BW}$. 
Groups IV, V, and VI were treatment groups receiving 100, 600, and $3000 \mathrm{mg} / \mathrm{kg} \mathrm{BW}$ of EEGP, each of which denoted as EEGP100, EEGP600, and EEGP3000. All steps of the experiment were performed ethically to avoid animals from suffering, and at the final step, all animals were sacrificed by cervical dislocation. These experiment procedures had been assessed by the Research Ethics Committee of the Muhammadiyah University of Purwokerto with the ethical approval document number KEPK/UMP/23/VI/2020.

\section{Ear edema test}

This assay followed the procedures described in Dunstan et al. (1997). The ear thickness of all groups was measured before and after the induction of edema. A total of $0.01 \mathrm{ml}$ of arachidonic acid $(0.58 \mathrm{mM}$ in $0.9 \% \mathrm{NaCl})$ was applied to the rat ears, and then the ear thicknesses were measured after $30,60,90,120,180$, and 240 minutes. The percentage of ear edema in each group was calculated using the formula below:

$$
\% \text { edema }=\frac{T t-T 0}{T 0} \times 100 \%
$$

where $T t=$ ear thickness after arachidonic acid injection, and $V 0=$ ear thickness before arachidonic acid application. Then, the percentage of edema inhibition was computed as follows:

$$
\% \text { edema inhibition }=\frac{a-b}{a} \times 100 \%
$$

where $a=\%$ edema of the control-solvent group, and $b=\%$ edema of the treatment groups.

\section{Hind-paw edema assay}

The assay was performed using plethysmography, a testing method created and introduced by Winter and colleagues decades ago but still extensively used until today (Rege et al., 2020). The hind paws were dipped into an apparatus containing mercury, then the number showing the mercury volume being increased due to the immersion was documented. This number represents the volume of the hind paw before the treatment (Vo). After the sub-plantar injection of $0.3 \mathrm{~mL}$ of $1 \%$ carrageenan, the volume of the induced edema was documented as volume after treatment $(\mathrm{Vt})$ at Minute 30, 60, 90, $120,180,250,300$, and 360 . The percentage of hind paw edema was then calculated using the formula below:

$$
\% \text { edema }=\frac{V t-V 0}{V 0} x 100 \%
$$

where $\mathrm{Tt}=$ volume of hind paw edema after carrageenan injection, and $\mathrm{T} 0=$ volume of hind paw before carrageenan injection. Then, the percentage of edema inhibition was calculated as follows:

$$
\% \text { edema inhibition }=\frac{a-b}{a} \times 100 \%
$$

where $\mathrm{a}=\%$ edema of the control-solvent group, and $\mathrm{b}=\%$ edema of the treatment groups.

Anti-platelet aggregation assay

Blood was drawn from the tails, added with $1 \%$ EDTA, mixed to prevent clotting, and centrifuged at $6,000 \mathrm{rpm}$ for 3 minutes. A total of $293.5 \mu \mathrm{l}$ of supernatant was then collected and 
added with $6.5 \mu \mathrm{l}$ of arachidonic acid to create a final concentration of $12.38 \mathrm{mM}$. The absorbances of the solution were measured at a wavelength of $655 \mathrm{~nm}$ using a microplate reader (iMark, Biorad) 15 seconds, 30 seconds, and minute for 10 minutes (Sukandar, 2008).

\section{Tail bleeding time assay}

Bleeding time assay was performed according to the procedures described in Min et al. (2012). After cutting off the tail tip, the bleeding area was dabbed with a filter paper (Whatman) every 30 seconds until the bleeding stopped (no apparent bloodstain on the paper). The time lapsed from tail tip amputation to cessation of bleeding was recorded as bleeding time.

\section{Data Analysis}

Percent edema inhibition (obtained from the ear and hind paw edema assay), changes in absorbance values (anti-platelet aggregation assay), and bleeding time were analyzed using two-way Analysis of Variance (ANOVA) in SPSS v.16.0 program.

\section{RESULTS AND DISCUSSION}

\section{EEGP exhibits anti-inflammation activity by reducing edema in rat ears and hind paws}

The anti-inflammatory properties of EEGP, as reported in Shah et al. (2011), was confirmed by the ear and hind paw edema assay. Ear edema is a symptom of inflammation and, in this study, was measured subsequent to the application of arachidonic acid, an edema inducer. Changes or swelling in ear thickness were observed by measuring the thickness of the pinna (auricle) using calipers. Percent edema represents the difference between ear thicknesses before and after its induction, while \% edema inhibition for each treatment group is expressed as the normalized value against the control-solvent group (Figure 1).

Figure 1 shows the percentage of ear edema inhibition from different treatment groups. Nadiclofenac and EEGP at all concentrations inhibited ear edema 90 minutes after the arachidonic acid injection. Na-diclofenac, as a positive control for edema inhibition, showed a larger percentage of inhibition compared to all concentrations of EEGP. EEGP100 could not inhibit the ear edema even after Minute 240, whereas EEGP600 and EEGP3000 exhibited inhibitory activities comparable to that of Na-diclofenac - as evident from $\mathrm{p}<0.05$ (statistically non-significant difference).

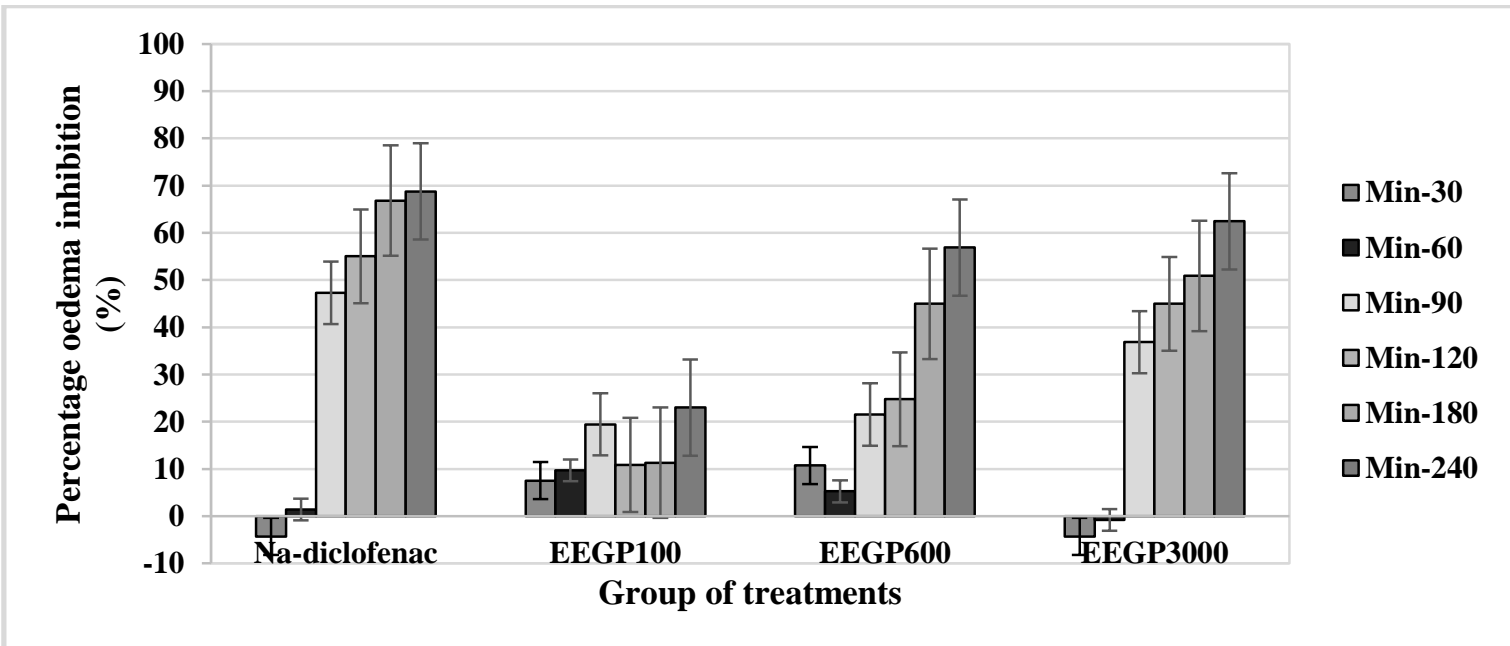

Figure 1. Percentage of edema inhibition in the ear edema assay. The percentage is the mean \pm SE values of triplicate experiments 
The hind paw edema assay was performed to support the results of the ear edema assay, which examined the anti-inflammatory activities of EEGP. Percent of carrageenan-induced edema in hind paws represents the difference between the volumes of edema before and after its induction, as observed using the plethysmograph instrument. Whether or not the drugs and EEGP could reduce these volumes, it is reflected by \% edema inhibition of each treatment group, which is a normalized value against the control-solvent group (Figure 2.).

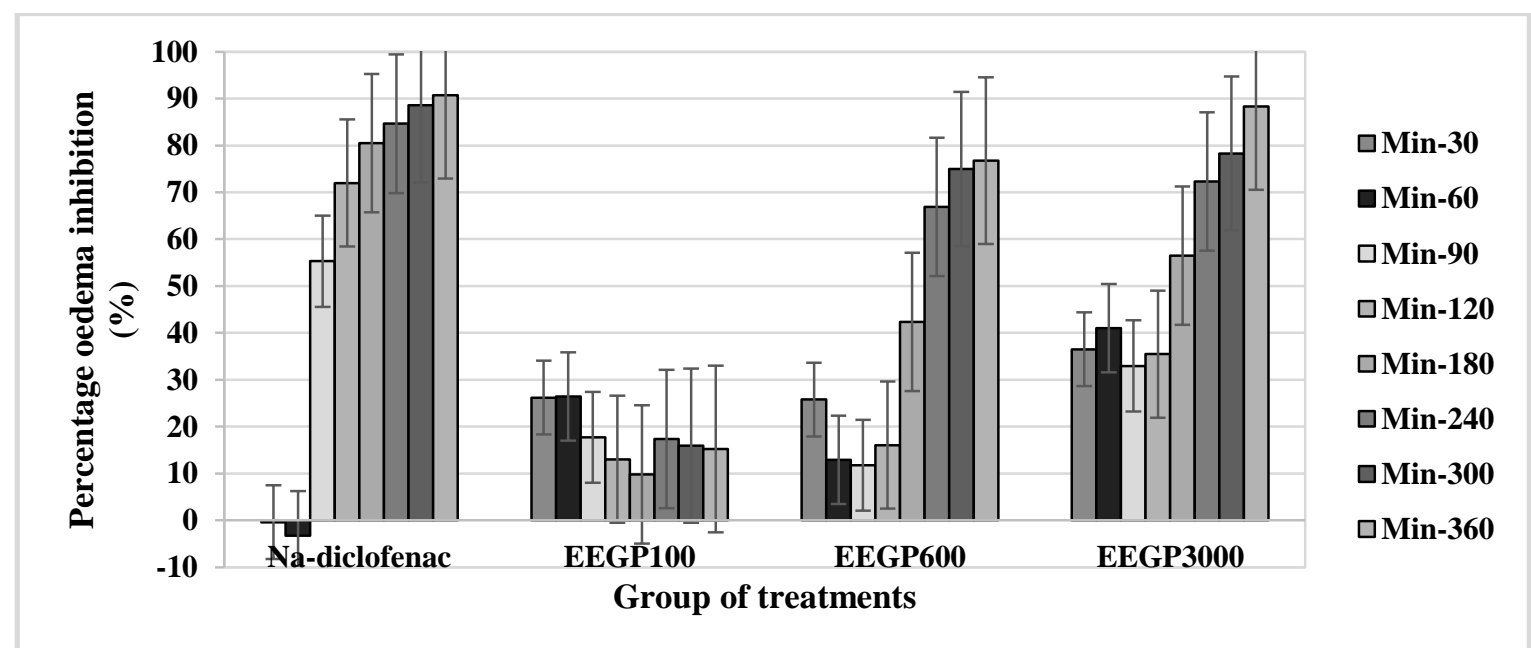

Figure 2. Percentage of edema inhibition in the hind paw edema assay. The percentage is the mean $\pm S E$ values of triplicate experiments

Figure 2 displays the percentage of hind paw edema inhibition in different treatment groups. Nadiclofenac, as a positive control, was found to inhibit hind paw edema in Minute 90 and exhibit increased inhibitory activities by up to $90 \%$ in Minute 360. EEGP100 did not impede this edema even after 360 minutes had passed from the carrageenan injection. Both EEGP600 and EEPG3000 exhibited signs of hind paw edema inhibition, which were not significantly different from the outcome of Nadiclofenac (p<0.05). EEGP600 had the same \% edema inhibition (i.e., 40\%) as EEGP3000 in Minute 180, which was 150 minutes later than EEGP3000. Nevertheless, no variety of \% edema inhibition was apparent in a more extended period (Minute 240 to 360).

The ear and hind paw edema assay revealed that unlike EEGP100, both EEGP600 and EEGP3000 could impede the progression and reduce edema. In addition, there was no statistical difference among the \% inhibitions in the ear and hind paw edema assay $(\mathrm{p}<0.05)$.

\section{EEGP inhibits platelet aggregation}

Arachidonic acid, as the platelet aggregation-triggering agent, binds to a platelet membrane receptor and, subsequently, activates the platelet to release its granule content, resulting in an increased rate of aggregation. Platelet activation or aggregation was observed based on the turbidimetry principle, i.e., from periodic changes in plasma absorbance at a wavelength of $655 \mathrm{~nm}$ (Sukandar, 2008). After the injection of arachidonic acid, plasma absorbance lowers as the platelet starts to form aggregates, reducing the turbidity of the plasma (Sukandar, 2008). Low plasma absorbance appears when platelet aggregation is inhibited. As seen in Table 1, EEGP100 showed immense changes changes in absorbance. Meanwhile, EEGP600 produced similar changes in absorbance as aspirin - a positive control in the experiment - and EEGP3000 showed smaller absorbance changes compared to aspirin. The absorbance changes of EEGP600 and EEGP3000 groups were not significantly different from the ones produced by aspirin, as evident from the statistical analysis results $(\mathrm{p}<0.05)$. 
Table 1. Platelet aggregation profiles after the administration of different concentrations of Graptophyllum pictum leaf extracts, as measured by absorbance changes in different points of time $(0.15,5$, and 10 minutes $)$

\begin{tabular}{|c|c|c|c|c|c|}
\hline $\begin{array}{c}\text { Treatment } \\
\text { Groups }\end{array}$ & $\begin{array}{c}\text { Minutes } \\
0.15\end{array}$ & $\begin{array}{c}\text { Minutes } \\
5\end{array}$ & $\begin{array}{c}\text { Minutes } \\
10\end{array}$ & $\begin{array}{c}\Delta \\
0.15-5\end{array}$ & $\begin{array}{c}\Delta \\
0.15-10\end{array}$ \\
\hline EEGP100 & $0.650 \pm 0.053$ & $0.512 \pm 0.183$ & $0.462 \pm 0.318$ & 0.138 & 0.189 \\
\hline EEGP600 & $0.373 \pm 0.057$ & $0.347 \pm 0.093$ & $0.332 \pm 0.112$ & 0.026 & 0.041 \\
\hline EEGP3000 & $0.209 \pm 0.112$ & $0.207 \pm 0.116$ & $0.212 \pm 0.111$ & 0.002 & -0.003 \\
\hline
\end{tabular}

Note: Absorbance values are presented as mean \pm SD of triplicate experiments. Minus (-) indicates an increase in absorbance. The absorbance changes $(\Delta)$ is the difference between the absorbance subtracted in Minute 0.15 and the absorbance of the respective time.

Bleeding time assay investigated the effects of EEGP, aspirin, and Na-diclofenac on hemostatic mechanism. In this experiment, anti-platelet aggregation is indicated by a longer bleeding time after the administration of EEGP. As seen in Table 2, all treatment groups required a more extended time to stop the bleeding after the tail tip amputation. Similar to the outcome of the ear and hind paw edema assay and anti-platelet aggregation assay, EEGP600 and EEGP3000 tended to exhibit the same effect as Na-diclofenac and aspirin, respectively. The statistical analysis revealed that the bleeding time of test rats receiving EEGP600 was not significantly different from the ones given Na-diclofenac $(\mathrm{p}<0.05)$. Comparable results were also identified between the EEGP3000 group and the positive control group, i.e., aspirin $(\mathrm{p}<0.05)$.

Table 2. The bleeding time after tail tip amputation in rats receiving Graptophyllum pictum leaf extracts, Na-diclofenac and aspirin (positive controls), and solvent (control)

\begin{tabular}{lc}
\multicolumn{1}{c}{ Treatment Groups } & Bleeding time (in s \\
\hline Solvent-control & $100 \pm 17.3$ \\
Positive control (Na-diclofenac) & $200 \pm 17.3$ \\
Positive control (Aspirin) & $220 \pm 45.8$ \\
EEGP100 & $120 \pm 0$ \\
EEGP600 & $170 \pm 17.3$ \\
EEGP3000 & $260 \pm 17.3$
\end{tabular}

Note: The bleeding time is the time elapsed between tail tip amputation and cessation of bleeding (no apparent bloodstain on the tissue paper) and is expressed as the mean $\pm \mathrm{SD}$ of triplicate experiments.

Except for EEGP100, both EEGP600 and EEGP3000 have been confirmed to possess antiinflammatory properties that are likely to inhibit platelet aggregation. This effect, indicated by a longer bleeding time, emerges due to the inhibited release of thromboxane A2 (Capurso and Capurso, 2020). However, it was contradictory to Tantio (2008), which reported that at $0.018 \mathrm{~mL} / \mathrm{gram}$ BW (or $\sim 100$ $\mathrm{mg} / \mathrm{kg} \mathrm{BW}$ ), Graptophyllum pictum results in a shorter bleeding time than the solvent-control group. Unfortunately, a direct comparison with Tantio (2008) is out of the question because this previous 
study only used one dose, i.e., $100 \mathrm{mg} / \mathrm{kg} \mathrm{BW}$. Even though, the same single dose has been proven to exhibit the effects of phlebotropic drug on hemorrhoids in a Wistar rat model (Hutagalung, 2019).

Bleeding can occur from the hemorrhoids process due to damages to hemorrhoid surfaces (Loder, 1994; Patil et al., 2019; Zeinalinejad et al., 2019). Accordingly, hemorrhoid treatments are also targeted at stopping or preventing anal bleeding in addition to inhibiting inflammation (Patil et al., 2019). However, the reduction of edema by anti-inflammatory agents can cause bleeding since the platelet aggregation is inhibited following the impeded release of thromboxane A2 (Capurso and Capurso, 2020). As confirmed in this current study, EEGP exhibited anti-inflammatory activities that induced the inhibition of platelet aggregation. Consequently, the development of G. pictum for antihemorrhoid based on its anti-inflammatory properties must factor in bleeding, as a potential side effect. In Astana (2017), when combined with Desmodium triquetrum leaves, Coleus atropurpureus leaves, Curcuma domestica rhizome, Curcuma xanthorriza rhizome, and Phylanthus niruri herbs, $30 \%$ G. pictum leaves are reportedly safe to use. However, at which range of dose G. pictum can exhibit anti-inflammatory activity without causing bleeding needs to be studied.

\section{CONCLUSION}

The ethanolic extract of Graptophyllum pictum leaves at doses of 600 and $3000 \mathrm{mg} / \mathrm{kg} \mathrm{BW}$ exhibit anti-inflammatory activities against arachidonic acid-induced ear edema and carrageenaninduced hind paw edema in Wistar rats, as evident from the inhibition of platelet aggregation. Therefore, it can be further developed as a potential treatment for hemorrhoids.

\section{ACKNOWLEDGMENT}

The authors would like to thank Mr. Rohmad Budi Setyanto for assisting in the extract preparation process.

\section{REFERENCES}

Astana, P., Ardiyanto, D., Triyono, A., Mana, T.A. (2017). Uji Keamanan dan Manfaat Ramuan Jamu untuk Hemoroid Dibandingkan dengan Diosmin Hisperidin. Media Litbangkes, 27, 57-64.

Capurso, A. \& Capurso, C. 2020. Hemostasis and Thrombosis. Principles of Nutrigenetics and Nutrigenomics. Elsevier.

Dunstan, C. A., Noreen, Y., Serrano, G., Cox, P. A., Perera, P. \& Bohlin, L. (1997). Evaluation of some Samoan and Peruvian medicinal plants by prostaglandin biosynthesis and rat ear oedema assays. Journal of Ethnopharmacology, 57, 35-56.

Goun, E., Cunningham, G., Chu, D., Nguyen, C. \& Miles, D. (2003). Antibacterial and antifungal activity of Indonesian ethnomedical plants. Fitoterapia, 74, 592-596.

Hutagalung, M. S. B. (2019). Phlebotrophic Effect of Graptophyllum Pictum (L.) Griff on Experimental Wistar Hemorrhoids. Journal of Biomedicine and Translational Research, 5, 14.

Jiangseubchatveera, N., Liawruangrath, B., Liawruangrath, S., Teerawutgulrag, A., Santiarworn, D., Korth, J. \& Pyne, S. G. (2015). The Chemical Constituents and the Cytotoxicity, Antioxidant and Antibacterial Activities of the Essential Oil of Graptophyllum pictum (L.) Griff. Journal of Essential Oil Bearing Plants, 18, 11-17.

Jiangseubchatveera, N., Liawruangrath, S., Teerawutgulrag, A., Santiarworn, D., Pyne, S. G. \& Liawruangrath, B. (2017). Phytochemical screening, phenolic and flavonoid contents, antioxidant and cytotoxic activities of Graptophyllum pictum (L.) Griff. Chiang Mai Journal of Science, 44, 193-202.

Loder, P. B., Kamm, M.A., Nicholls, R.J., Phillips, K., S. (1994). Haemorrhoids: pathology, pathophysiology and aetiology. British Journal of Surgery, 1994, 946-954.

Lohsiriwat, V. (2012). Hemorrhoids: from basic pathophysiology to clinical management. World journal of gastroenterology, 18, 2009-2017. 
Min, S. K., Kwon, O. C., Lee, S., Park, K. H. \& Kim, J. K. (2012). An antithrombotic fucoidan, unlike heparin, does not prolong bleeding time in a murine arterial thrombosis model: a comparative study of Undaria pinnatifida sporophylls and Fucus vesiculosus. Phytotherapy research, 26, 752-757.

Olagbende-Dada, S., Ogbonnia, S., Coker, H. \& Ukpo, G. (2011). Blood glucose lowering effect of aqueous extract of Graptophyllum pictum (Linn) Griff. on alloxan-induced diabetic rats and its acute toxicity in mice. African Journal of Biotechnology, 10, 1039-1043.

Patil, S. V., Veerendra, M. \& Shinde, N. (2019). Management of haemorrhoids in tertiary care centre. International Journal of Surgery, 3, 217-219.

Rege, M. G., Ayanwuyi, L. O., Zezi, A. U. \& Odoma, S. (2020). Anti-nociceptive, anti-inflammatory and possible mechanism of anti-nociceptive action of methanol leaf extract of Nymphaea lotus Linn (Nymphaeaceae). Journal of Traditional and Complementary Medicine [Online]. Available: http://www.sciencedirect.com/science/article/pii/S2225411020302169 [Accessed 2020/02/28/].

Shah, B. N., Seth, A.K., and Maheshwari, K.M. (2011). A Review on Medicinal Plants as a Source of Anti-inflammatory Agents. Research Journal of Medicinal Plants, 5, 101-115.

Srinivasan, K. K., Mathew, J. E., Joseph, K., Vachala, S. D. \& Malini, S. (2011). Effect of ethanol extract of Graptophyllum pictum (L.) Griff. on cisplatin induced nephrotoxicity in rats. Herba polonica, 57.

Sukandar, E. Y., Sigit, J.I., Fitriyani, N. (2008). Efek antiagregrasi platelet ekstrak air bulbus bawang putih, ekstrak etanol rimpang kunyit dan kombinasinya pada Mencit Galur Swiss Webster. Majalah Farmasi Indonesia, 19, 1-11.

Sya'haya, S., Iyos, R.N. (2016). Pengaruh pemberian ekstrak daun ungu (Graptophyllum pictum Griff) terhadap penyembuhan hemoroid. Majority, 5, 155-160.

Tantio, D. a. E. 2008. Pengaruh pemberian ekstrak daun ungu (Graptophyllum pictum (L) Griff) terhadap waktu perdarahan (Bleeding Time) pada tikus wistar jantan. Bachelor Thesis, Universitas Jember.

Zeinalinejad, H., Pourseyedi, B., Rahmani, H., Najmadini, M., Ebrahimi, M., Jashnani, M. S., Naghdi, R. \& Pourdavood, A. H. (2019). Clinical complications of hemorapy device versus MilliganMorgan hemorrhoidectomy in patients with hemorrhoids in 2017-2018. Journal of Surgery and Trauma, 7, 135-140. 